\title{
Risky Behaviours of Middle School Students in Vlore
}

\author{
Majlinda Zahaj1* , Sidorela Senka ${ }^{1}$ and Emirjona Kiçaj ${ }^{2}$ \\ ${ }^{1}$ Department of Nursing, Faculty of Health, University "Ismail Qemali", Albania \\ ${ }^{2}$ Department of Health Care, Faculty of Health, University "Ismail Qemali", Albania \\ *Corresponding author: Majlinda Zahaj, Department of Nursing, Faculty of Health, University “Ismail Qemali”, Albania
}

ARTICLE INFO

Received: 慧 June 10, 2021

Published: 幽 June 21, 2021

Citation: Majlinda Zahaj, Sidorela Senka, Emirjona Kiçaj. Risky Behaviours of Middle School Students in Vlore. Biomed J Sci \& Tech Res 36(4)-2021. BJSTR. MS.ID.005885.

Keywords: Smoking; Alcohol; Marijuana; Adolescence; Risky Behaviors

\begin{abstract}
Introduction: Risky behaviors are a group of behaviors that affect the mental, physical and social health of children. As the 14-15 age group is in a period of transition between childhood and adolescence, they are more vulnerable to harmful behaviors as their personality is not yet fully formed.
\end{abstract}

Purpose of the Study: Evaluation of risky behavior, namely smoking, consuming alcohol, and marijuana in individual classes 7, 8, and 9th in the public schools of the city of Vlora.

Materials And Methods: This is a cross-sectional study that was attended by 390 students of 9 - year schools in the city of Vlora aged 13-16 years. Data collection was performed through the use of a self-administered questionnaire.

Results: After processing the data, it turned out that $64 \%$ had tried smoking at least once in their lives, mainly at the age of 13-14, and it was women who had experienced smoking the fastest. Meanwhile, $89.1 \%$ of participants reported having used alcohol at least once. It was men who referred to alcohol use and the initial age of alcohol consumption is $11-12$ years (58\%). Only $0.6 \%$ of participants reported having tried marijuana and the initial age when using it was 11-12 years old.

Conclusions: Significantly influencing factors in tobacco use include curiosity ( $\mathrm{P}$ $=0.011)$, smoking by society $(\mathrm{P}=0.0001)$, the idea that smoking relieves stress $(\mathrm{P}=$ $0.002)$, the opinion that smoking quenches appetite and weakens $(P=0.009)$, parental smoking $(\mathrm{P}=0.015)$, smoking as a form of parental rebellion $(\mathrm{P}=0.03)$, smoking as a form of breaking daily routine $(\mathrm{P}=0.001)$ as well as smoking helps in socialization $(\mathrm{P}$ $=0.04)$. Society is a very strong influence on the use of alcoholic beverages $(\mathrm{P}<0.05)$. All mothers who are non-casual users of tobacco and alcoholic beverages are likely to become casual users of marijuana, so try it but not use it regularly.

\section{Introduction}

Risky behaviors are a set of behaviors that affect the mental, physical and social health of children. As the 14-15 age group is in a period of transition between childhood and adolescence, they are more vulnerable to harmful behaviors as their personality is not yet fully formed. Factors such as low socio-economic level, inadequate social conditions, limited educational opportunities can negatively affect adolescence. Adolescents are more likely to engage in risky behaviors than older individuals [1]. Multiple risky behaviors such as smoking, anti-social behaviors, alcohol consumption, and unprotected sex are also associated with poor achievement in education, increased morbidity, and increased premature mortality. The prevalence of the number of risk behaviors varies by gender, for example, girls have a higher commitment towards smoking, self-harm, or lack of physical activity. In contrast, antisocial, criminal behaviors, cannabis use, and vehicle-related risk behaviors are more prevalent among men [2]. Young people who start smoking at the age of 14-15 years show at the age of 24, a 
lung capacity of $10 \%$ less compared to peers who have not smoked [3]. In addition to smoking and alcohol use constitutes problematic behavior in adolescents. The preferred time to drink alcoholic beverages is when they associate with each other [4]. Studies have shown that those who start using alcohol in significant doses during adolescence tend to become regular users, develop alcohol addiction, have mental health problems, lower learning outcomes, and a greater risk of getting involved. in crimes in later years [5].

Marijuana use is also steadily increasing among young people. Drug use is often influenced by social pressure in adolescence [6]. Factors influencing the use of harmful substances to health in adolescence are many such as individual characteristics [7]; mental health and neurological development [7-9]; genetic changes [10]; family support [11]; education [11; a very influential factor is the influence of peers [12]; physical and emotional abuse of children [13]; etc.

\section{Aim of the Study}

Evaluation of risky behaviors, namely smoking, consumption of alcoholic beverages, and marijuana, in individuals of $7^{\text {th }}, 8^{\text {th }}$ and $9^{\text {th }}$ grades, in public schools in the city of Vlora.

\section{Materials and Methods}

This is a cross-sectional study, conducted during the period March-May 2019. This study was attended by 3,60 students of $7^{\text {th }}, 8^{\text {th }}$ and $9^{\text {th }}$ grades of 9 -year schools in the city of Vlora, Albania. Since the purpose of this paper is to assess risky behaviors in the age group 13-16 years, students of 7th, 8th and 9th grades were interviewed, in which you can find individuals of this age group. A total of 360 students were included in the study. The data of this paper were collected through a self-administered questionnaire. The design of the questionnaire was based on standardized questionnaires about risky behaviors in these age groups. The questionnaire which was taken as a reference can be mentioned the Youth Risk Behavior Questionnaire, which has free access. From this questionnaire were taken questions that have to do with determining the frequency and amount of smoking, alcohol, or marijuana. Questions from the Youth Tobacco Questionnaire or the GYTS Core Questionnaire were also used. Questions were taken from the above questionnaires which are thought to fit the Albanian society.

a) The first part of the questionnaire. Includes questions where information is obtained about: age, gender, the amount of money a student spends during the week.

b) In the second part of the questionnaire, some questions aim to determine the frequency of use throughout the life of tobacco, smoking during the last month, the number of cigarettes consumed per day, factors that may affect the consumption of tobacco.

c) In the third part of the questionnaire, questions are included which aim to assess the consumption of alcoholic beverages at these ages throughout life and during the last 30 days, factors that may affect the consumption of alcoholic beverages by the age group 13-16 years old.

d) The fourth part includes questions aimed at gathering information on marijuana use, from the age at which it was first tried, to its use during the last 30 days.

Data processing was performed through the SPSS data processing program, version 22. The tests used are depending on the type of variables.

\section{Ethical Considerations}

To carry out this study was provided ethical permission from the Faculty of Health addressed to the Vlora Regional Education Directorate to allow the realization of this study.

\section{Results of the Study}

The average age of the interviewed youth is $\mathrm{X}=14.5$ years. 0.624 . The age of the respondents was concrete: $4 \%$ were 13 years old, $43 \%$ were 14 years old, 50\% were 15 years old and 3\% 16 years old. Most of the interviewed cases were male, $60 \%$ of the cases, therefore $40 \%$ of the interviewed adolescents are female. Most of the young people included in the study, about $65 \%$, spend more than 2000 new lekë, followed by $21 \%$ who spend 1000-2000 new lekë. Very small percentages then spend more than 1000 new lek. To the question "Have you ever tried a cigarette?" 64.4\% referred that they had tried the cigarette at least once (Table 1). If the question of the first $35.6 \%$ of respondents said they have never tried smoking, the question of the next $36.7 \%$ says they have never tried to prove it. We see that most of the young people interviewed, about $23 \%$ of the total, have tried smoking at the age of 13-14. There is a group of young people, $22 \%$, who have tried smoking at the age of 9-10. Although there are few cases, only $3 \%$, there are individuals who have tried smoking under the age of 8 years. In the table below we see that between the gender of the interviewees and the age when these young people have tried smoking for the first time is significant, because $\mathrm{P}=0.002$, ie $\mathrm{P}<0.05$, which means that women are the ones who have experimented before. with tobacco, compared to men (Tables 2-5). 


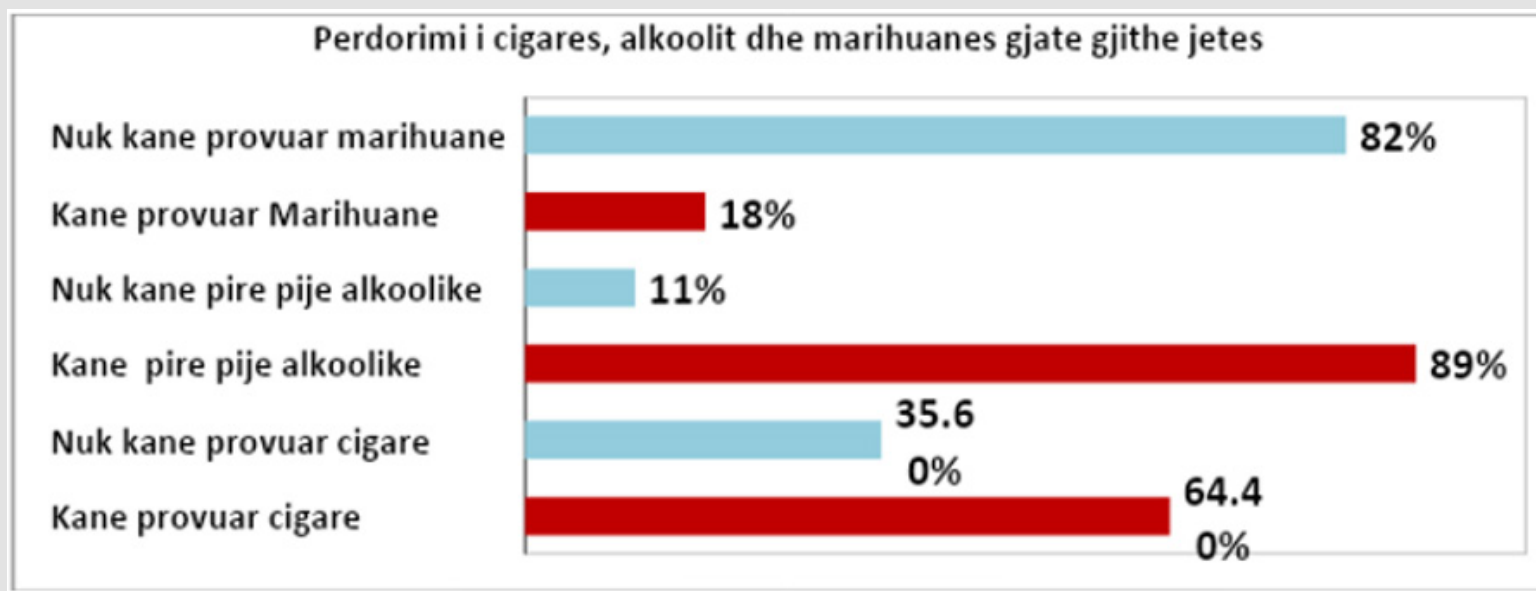

Graph 1: The graph above summarizes the lifetime frequency of tobacco, alcohol, and marijuana use of the interviewed students (casual users).

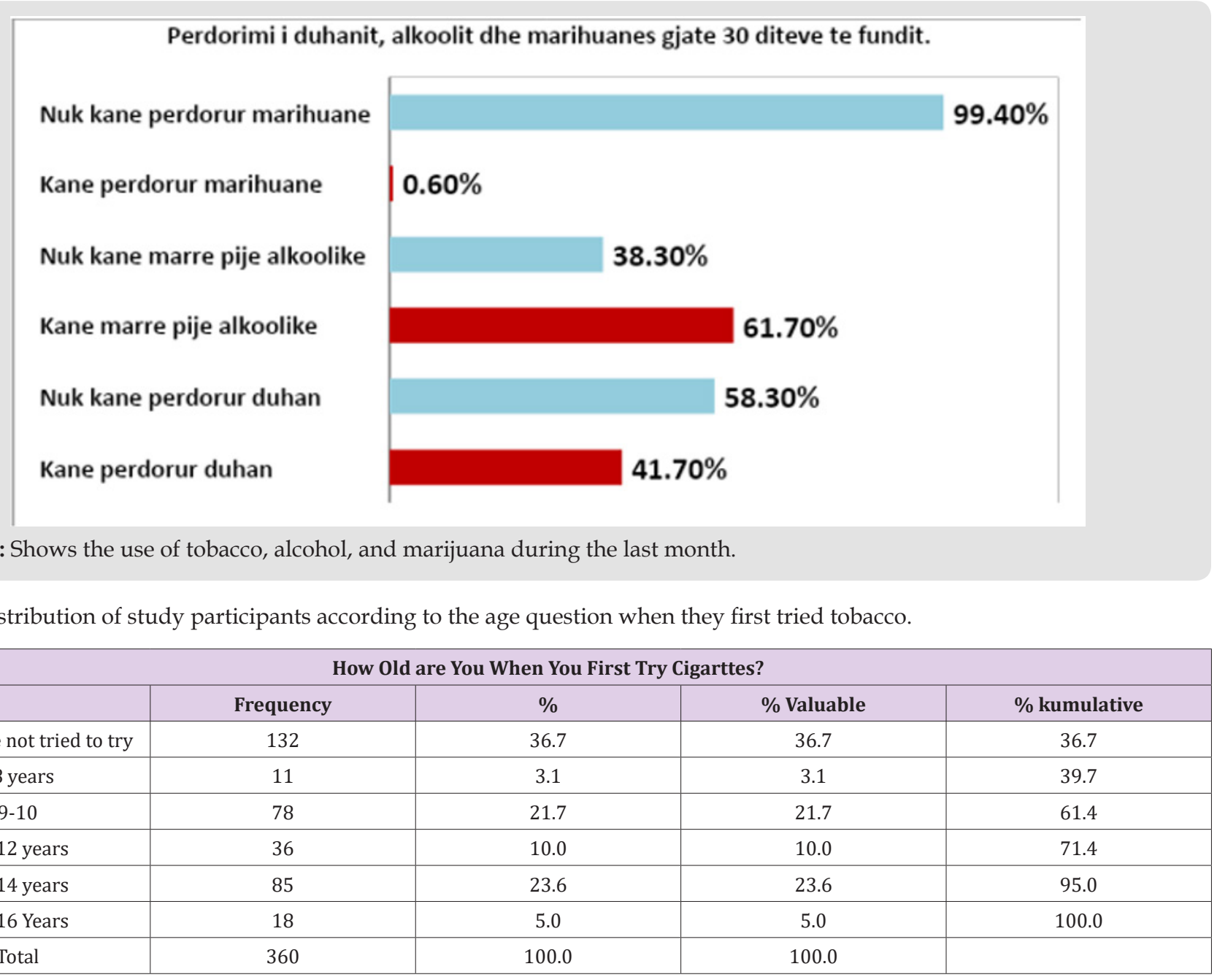

Table 2: Relationship between age when smoking was first tried.

\begin{tabular}{|c|c|c|c|c|c|}
\hline \multicolumn{6}{|c|}{ Coefficients $^{\mathrm{a}}$} \\
\hline \multirow{2}{*}{ Model } & \multicolumn{2}{|c|}{ Unstandardized Coefficients } & \multirow{2}{*}{$\begin{array}{c}\text { Standardized Coefficients } \\
\text { Beta }\end{array}$} & \multirow{2}{*}{$\mathbf{t}$} & \multirow{2}{*}{ Sig. } \\
\hline & B & Std. Error & & & \\
\hline 1 Gender & 1.097 & .177 & .311 & 6.192 & 0.02 \\
\hline
\end{tabular}


Table 3: Distribution of participants according to the number of cigarttes smoked during the last 30 days and gender.

\begin{tabular}{|c|c|c|c|}
\hline \multicolumn{4}{|c|}{ Count } \\
\hline & \multicolumn{2}{|c|}{ Gender } & \multirow{2}{*}{ Total } \\
\hline & Female & Male & \\
\hline \multirow{2}{*}{$\begin{array}{l}\text { How many cigarettes does Aire have per day during }<1 \text { cigartte? } \\
\text { these last } 30 \text { days? } 1 \text { cigartte }\end{array}$} & 121 & 81 & 202 \\
\hline & 18 & 69 & 87 \\
\hline 2-5 cigar & 4 & 56 & 60 \\
\hline $6-10$ & 2 & 5 & 7 \\
\hline $11-20$ & 0 & 4 & 4 \\
\hline Total & 145 & 215 & 360 \\
\hline
\end{tabular}

Table 4: Distribution of participants according to the number of cigarettes smoked during the last 30 days and age.

\begin{tabular}{|c|c|c|c|c|c|}
\hline \multicolumn{6}{|c|}{ Age } \\
\hline & 13 & 14 & 15 & 16 & Total \\
\hline $\begin{array}{l}\text { How many cigarettes do you smoke per day during }<1 \\
\text { cigarette }\end{array}$ & 11 & 108 & 80 & 3 & 202 \\
\hline these last 30 days? 1 cigarette & 0 & 30 & 56 & 1 & 87 \\
\hline 2-5 cigar & 2 & 13 & 40 & 5 & 60 \\
\hline $6-10$ & 0 & 3 & 2 & 2 & 7 \\
\hline $11-20$ & 1 & 2 & 1 & 0 & 4 \\
\hline Total & 14 & 156 & 176 & 11 & 360 \\
\hline
\end{tabular}

Table 5: Gender relationship versus frequency and amount of cigarettes consumed.

\begin{tabular}{|c|c|c|c|}
\hline \multirow{4}{*}{\multicolumn{2}{|c|}{ During the 30 clits of funclit how many times did you smoke? }} & \multicolumn{2}{|c|}{ Gender } \\
\hline & & \multicolumn{2}{|c|}{.472} \\
\hline & & \multicolumn{2}{|c|}{.002} \\
\hline & & \multicolumn{2}{|c|}{360} \\
\hline \multirow{3}{*}{\multicolumn{2}{|c|}{$\begin{array}{l}\text { How many cape cigarettes did you smoke per day during these last } 30 \\
\text { days? }\end{array}$}} & \multicolumn{2}{|c|}{.419} \\
\hline & & \multicolumn{2}{|c|}{.001} \\
\hline & & \multicolumn{2}{|c|}{360} \\
\hline \multicolumn{2}{|c|}{$\begin{array}{l}\text { The following tables provide an estimate of the relationship } \\
\text { between gender and the frequency and quantity of cigarettes } \\
\text { consumed. We see that this relationship is not accidental but has } \\
\text { a significant character. So, it is men who smoke more frequently, } \\
\text { and even consume larger amounts of cigarettes per day compared } \\
\text { to women, respectively (P = } 0.002 \text { and } \mathrm{P}=0.001) \text {. In the following } \\
\text { descriptive table, obtained through crosstabulation and Pearson } \\
\text { Coefficient estimation, we see the impact of the factors mentioned } \\
\text { above on tobacco consumption. We see that curiosity is a significant } \\
\text { influencing factor, so young people who smoke are significantly and } \\
\text { not randomly influenced by curiosity, } \mathrm{P}=0.011 \text {. There is a strong }\end{array}$} & \multicolumn{2}{|c|}{$\begin{array}{l}\text { significant relationship between tobacco consumption by society } \\
\text { and its consumption, as } \mathrm{P}=0.0003 \text {, showing the strong influence } \\
\text { of society on this behavior. Also, significant influences on smoking } \\
\text { are young people's perceptions that smoking relieves stress ( } \mathrm{P}= \\
0.002 \text { ) or smoking quenches appetite and helps you lose weight } \\
(\mathrm{P}=0.009 \text { ). Also, the thoughts that smoking is a form of rebellion } \\
\text { or a way to break the routine, significantly affect the frequency of } \\
\text { smoking in the interviewed ages (respectively } \mathrm{P}=0.03 \text { and } \mathrm{P}= \\
0.001 \text { ) Children whose parents smoke are more likely to smoke (P } \\
=0.015 \text { ) (Tables } 6 \& 7) \text {. }\end{array}$} \\
\hline & \multicolumn{3}{|c|}{ During the last 30 days how, many times have you smoked a cigarette? } \\
\hline & Person & P-value & $\mathbf{N}$ \\
\hline Curiosity & .134 & .011 & 360 \\
\hline Smoking is a sign of maturity & .087 & .99 & 360 \\
\hline If the mycelium consumes it then I will consume it too & .186 & .000 & 360 \\
\hline Smoking relieves stress & .159 & .002 & 360 \\
\hline
\end{tabular}




\begin{tabular}{|c|l|l|l|}
\hline Smoking whets your appetite, and you lose weight & .137 & .009 & 360 \\
\hline Parent's smoke & .127 & .015 & 360 \\
\hline smoking helps in concentration & .081 & .125 & 360 \\
\hline It is a form of rebellion & .115 & .001 & 360 \\
\hline It is a form of breaking the daily routine & .176 & .040 & 360 \\
\hline Smoking helps in socialization & .106 & .011 & 360 \\
\hline you look fashionable when you smoke cigarettes & .133 & 360 \\
\hline
\end{tabular}

Table 7: Distribution of participants in the study according to access to alcoholic beverages.

\begin{tabular}{|c|c|c|c|c|}
\hline \multicolumn{5}{|c|}{ How old were you when you drank your first alcoholic beverage } \\
\hline & Frequency & \% & \% available & \% cumulative \\
\hline Valid I did not drink & 40 & 11.1 & 11.1 & 11.1 \\
\hline$<$ 8 years & 10 & 2.8 & 2.8 & 13.9 \\
\hline $9-10$ years & 48 & 13.3 & 13.3 & 27.2 \\
\hline $11-12$ years & 208 & 57.8 & 14.8 & 95 \\
\hline $13-14$ years & 53 & 14.7 & 0.3 & 100 \\
\hline $15-16$ years & 1 & 0.3 & 100 & \\
\hline Total & 360 & 100 & & \\
\hline
\end{tabular}

Most of the respondents, 58\%, consumed alcohol for the first time when they were 11-12 years old, $14 \%$ at the age of 13-14 years, $13 \%$ consumed alcohol for the first time at the age of 9-10 years, about 3\% have tried alcohol when they were younger than 8 years old and $11 \%$ say they have never drunk alcohol in their lifetime (Table 8). 49\% of the interviewed cases say that teenagers consume alcohol because they want to rebel against their parents, $54 \%$ say that young people consume alcohol because they want to feel good because they are upset, $67.5 \%$ of cases think that teenagers consume alcoholic beverages because they want to pass pleasant time at the party, while in most cases, $73 \%$ think that young people consume alcohol because they want to adapt to society (Table 9). In the table above we see that the only factor that significantly affects alcohol consumption is the need to adapt to society, as $\mathrm{P}$ $<0.05$. It has a positive impact on society on alcohol consumption throughout life $(\mathrm{P}=0.003)$, it also has a significant positive impact on alcohol consumption over the last 30 days.

Table 8: Distribution of participants in the study according to access to alcoholic beverages.

\begin{tabular}{|c|c|c|c|}
\hline \multicolumn{4}{|c|}{ Descriptive Statistics } \\
\hline & $\mathbf{N}$ & $\%$ & Std.Deviation \\
\hline I gave the money to someone else to buy it in my country & 359 & 1.3 & 0.117 \\
\hline I got it secretly in the store & 360 & 3 & 0.172 \\
\hline I bought it during a public event & 359 & 4.7 & 0.213 \\
\hline someone else gave it to me & 360 & 12.5 & 0.331 \\
\hline I bought it in the store as a liquor store, supermarket, etc. & 360 & 13.6 & 0.355 \\
\hline I secured it in another way & 359 & 14.7 & 0.378 \\
\hline Well, not a rehab, a bar, a club & 360 & 17.2 & 0.484 \\
\hline I have not had a drink in the last 30 days & 360 & 37.2 & \\
\hline Valid N (listwise) & 357 & & \\
\hline
\end{tabular}

Table 9: Evaluation of influencing factors in the use of alcoholic beverages.

\begin{tabular}{|c|c|c|}
\hline & $\begin{array}{l}\text { During the last } 30 \text { days, on how many days } \\
\text { have you consumed alcoholic beverages? }\end{array}$ & $\begin{array}{l}\text { Throughout your life, in how many days have } \\
\text { you drunk at least one alcoholic drink }\end{array}$ \\
\hline \multirow{3}{*}{ They want to have a good time at the party } & 0.035 & 0.098 \\
\hline & 0.506 & 0.063 \\
\hline & 360 & 360 \\
\hline \multirow{3}{*}{ They want to feel good because they are upset } & 0.004 & 0.102 \\
\hline & 0.943 & 0.053 \\
\hline & 360 & 360 \\
\hline
\end{tabular}




\begin{tabular}{|c|c|c|}
\hline \multirow{3}{*}{ They want to rebel against their parents } & 0.024 & 0.092 \\
\cline { 2 - 3 } & 0.653 & 0.081 \\
\cline { 2 - 3 } & 360 & 360 \\
\hline \multirow{3}{*}{ They want to interact with society } & 0.127 & 0.159 \\
\cline { 2 - 3 } & 0.017 & 0.003 \\
\cline { 2 - 3 } & 360 & 360 \\
\hline
\end{tabular}

Evaluation of Marijuana or Hashish Use at Interviewed Ages

In this part of the questionnaire are placed 4 questions which receive information about the use of marijuana throughout life, its frequency in the last 30 days, and the initial age when this substance was tested (Table 10). 81\% of respondents have never used marijuana in their lifetime, only 1\%, 5 cases, have used marijuana in 10-19 days of their life, $13 \%$ have used such a substance in 20-39 days in total, $4 \%$ have used hashish in 40-99 days. $81 \%$ say again that they have never tried marijuana. $1 \%$ of respondents have tried this drug younger than 8 years old, $3 \%$ have tried it when they were 9-10 years old, 9\% have tried it during the age of 11-12 years, $4 \%$ during the age of $13=14$ years and $2 \%$ have tried marijuana between the ages of $15-16$ (Table 11 ). We see that $98 \%$ of the interviewed cases have not used marijuana in the last 30 days. A small percentage of $0.6 \%$ or only 2 cases have used marijuana 1 to 2 times in the last month.

Table 10: Distribution of participants by marijuana use over the last 30 days.

\begin{tabular}{|c|c|c|c|c|c|}
\hline \multicolumn{7}{|c|}{ Throughout your life, how many times have you used marijuana } \\
\hline & & Frequency & Percent & Valid Percent & Cumulative percent \\
\hline \multirow{3}{*}{ Valid } & 0 here & 293 & 81.4 & 82.1 & 82.1 \\
\cline { 2 - 6 } & $10-19$ here & 5 & 1.4 & 1.4 & 83.5 \\
\cline { 2 - 6 } & $20-39$ here & 45 & 12.5 & 3.9 & 100 \\
\hline & $40-99$ here & 14 & 99.9 & 100 & \\
\hline & Total & 357 & 0.8 & & \\
\hline
\end{tabular}

Table 11: Distribution of participants by marijuana use over the last 30 days.

\begin{tabular}{|c|c|c|c|c|c|}
\hline \multicolumn{7}{|c|}{ Over the last 30 days how many times have you used Marijuana } \\
\hline & & Frequency & Percent & Valid Percent & Cumulative percent \\
\hline \multirow{3}{*}{ Vallid } & 0 here & 355 & 98.6 & 99.4 & 99.4 \\
\cline { 2 - 6 } & $1-2$ here & 2 & 0.6 & 0.6 & 100 \\
\cline { 2 - 6 } & Total & 357 & 99.2 & & \\
\hline Missing & System & 3 & 0.8 & & \\
\hline Total & & 360 & 100 & & \\
\hline
\end{tabular}

Assessing the Relationship Between Tobacco, Alcohol, and Marijuana Consumption

To see the action of these variables on each other their relationship is estimated, by calculating the coefficient Person. Relationship Smoking vs. Alcohol Consumption. If we look at the table below, cigarette consumption significantly affects the consumption of alcoholic beverages, and vice versa, since $\mathrm{P}=$ 0.0003 . So, a teenager who smokes is more likely to consume alcoholic beverages as well. This relationship is significant, with a positive character, so the increase of one of the variables leads to the increase of the other variable and vice versa. Cigarette consumption in the last 30 days has also affected the number of lifetime marijuana use, as $\mathrm{P}=0.0001$. So, we can say that smoking during the last month, has a very strong impact on marijuana testing during life, but has no impact on its use during the last month as $\mathrm{P}=0.206$. In short, we can say that a young person who regularly smokes tends to try marijuana, but not necessarily to use it regularly. The same relationship exists between alcohol use and lifelong marijuana use. Cases that use alcohol regularly, or during the last month tend to try marijuana $(\mathrm{P}=0.003)$ but not use it regularly (as $\mathrm{P}=0.612$ ) (Tables 12-14). Which gender uses the most alcohol and marijuana? If we look at the table below, we can say that it is men who consume alcoholic beverages at the highest frequency since $\mathrm{P}=0.0001$. no statistical dependence was observed between gender and marijuana use as $\mathrm{P}=0.781$. 
Table 12: Assessing the relationship between alcohol use and smoking.

\begin{tabular}{|c|c|c|c|c|}
\hline & $\begin{array}{c}\text { During the last 30 days } \\
\text { how many times have you } \\
\text { smoked cigarettes? }\end{array}$ & $\begin{array}{c}\text { During the last 30 days, } \\
\text { on how many days have } \\
\text { you consumed alcoholic } \\
\text { beverages? }\end{array}$ & $\begin{array}{c}\text { How many times in the } \\
\text { last 30 days have you used } \\
\text { Marijuana? }\end{array}$ & $\begin{array}{c}\text { How many times in } \\
\text { your life have you used } \\
\text { narijuana? }\end{array}$ \\
\hline \multirow{2}{*}{$\begin{array}{c}\text { During the last 30 days } \\
\text { how many times have you } \\
\text { smoked cigarettes? }\end{array}$} & & 0.404 & 0.067 & 0.428 \\
\cline { 2 - 5 } & & 0 & 0.206 & 0 \\
\hline $\begin{array}{c}\text { During the last 30 days, } \\
\text { on how many days have } \\
\text { you consumed alcoholic } \\
\text { beverages? }\end{array}$ & 0.406 & 360 & 357 & 357 \\
\cline { 2 - 5 } & 0 & & 0.027 & 0.159 \\
\hline
\end{tabular}

Table 13: Assessing the relationship between tobacco use and marijuana.

\begin{tabular}{|c|c|c|c|c|c|c|}
\hline \multicolumn{7}{|c|}{ Count } \\
\hline & \multicolumn{5}{|c|}{ How many times in your life have you used marijuana? } & \multirow{2}{*}{ Total } \\
\hline & & & 10-19 here & 20-39here & 40-99 here & \\
\hline \multirow[t]{2}{*}{$\begin{array}{l}\text { Have you ever tried } \\
\text { cigarettes? }\end{array}$} & JO & 125 & 2 & 1 & 0 & 128 \\
\hline & P0 & 168 & 3 & 44 & 14 & 229 \\
\hline Total & & 293 & 5 & 45 & 14 & 357 \\
\hline
\end{tabular}

Table 14: Assessing the relationship between gender and alcohol and marijuana use.

\begin{tabular}{|c|c|}
\hline \multicolumn{2}{|c|}{ Gjinia } \\
\hline \multirow{3}{*}{$\begin{array}{c}\text { During the last } 30 \text { days, on how many days have you consumed alcoholic } \\
\text { beverages? }\end{array}$} & 0.286 \\
\hline & 0 \\
\hline & 386 \\
\hline \multirow{3}{*}{ How many times in the last 30 days have you used Marijuana? } & 0.015 \\
\hline & 0.781 \\
\hline & 357 \\
\hline
\end{tabular}

\section{Discussion}

Risky behaviors are influenced by a wide range of factors, ranging from gender, culture, family, personal perceptions, to society as a whole. Some adolescents are more likely to engage in risky behaviors than other people who are more withdrawn. Many adolescents tend to seek new sensations, strong and exciting experiences, to break their daily routine. Also, the very concept of misbehavior is relative, as adolescents can perceive risk in different ways, based on concepts created in their families. Many young people do not see anything wrong with their dangerous behavior, nor do they even think about the negative consequences of their behavior. Also, many adolescents are influenced by society as a result of the need to adapt to them, embracing behaviors that are "normal" for the group of society. According to the Australian web publications reisingchildren.net.au, society doubles the risk of risky behavior $[14,15]$. A study conducted by the Center for Disease Control, conducted in 2017, shows that the earlier the time to start smoking, the greater the chances of becoming addicted to nicotine. As many as $90 \%$ of adult smokers have been regular smokers since adolescence or earlier. In this paper, it was seen that during the last 30 days consumed alcohol about $61.7 \%$ of respondents. The age at which alcohol consumption started was 1f1-12 years old, with a percentage of $57.8 \%$. It was also seen that it was men who consumed more alcohol than women $(\mathrm{P}=0.0003)$.

In the study conducted by ESPAD, in collaboration with the Institute of Public Health, in 2015 and published in 2016, about $65.7 \%$ of respondents had used at least 1-2 drinks in their lifetime, even the tendency to consume alcohol at these ages has been increasing from 2011 to 2015 [16]. While in our case it turned out that a larger percentage of teenagers, of $89.1 \%$, had tried 1-2 drinks in their lifetime. According to data obtained again from Public Health, obtained through the ESPAD project, the factors that significantly affected the prevalence of smoking were friends who smoked and the difficulty in finding cigarettes. According to these data, having friends who smoke increases by 2.3 times the likelihood of self-use of tobacco and 1.5 times the chances of using alcohol at these ages. In this paper, it is seen that very important influencers in smoking are the curiosity of young people to try what it is like to smoke cigarettes $(\mathrm{P}=0.011)$, or the thoughts that smoking looks fashionable, or breaks the daily routine. Very strong 
influences on smoking are the influence of society and smoking by the parents of the interviewed students $(\mathrm{P}=0.0001$ and $\mathrm{P}=0.015)$. Also, many of the young people who smoke think that smoking cigarettes helps you lose weight or smoking helps you socialize, so you can have a lot of friends $(\mathrm{P}=0.009$ and $\mathrm{P}=0.040)$. In terms of alcohol consumption, the only significant influencing factor is again the influence of society, so young people consume alcohol as they seek to adapt to their society.

\section{Conclusions}

About $64 \%$ have tried cigarettes at least once in their lifetime, while they have used cigarettes in the last 30 days about $41.7 \%$, where most, about $24 \%$ have smoked only 1 cigarette. When smoking was first tried, the initial age is 13-14 years old, at a rate of $24 \%$, and it is women who have experimented earlier, compared to men. But it is men who have the highest frequency of smoking. Significantly influencing factors in tobacco use are mentioned when curiosity $(P=0.011)$, smoking by society $(P=0.0001)$, the idea that smoking relieves stress $(\mathrm{P}=0.002)$, the opinion that smoking quenches appetite and weakens $(\mathrm{P}=0.009)$, the consumption of tobacco from the parent's rite $(\mathrm{P}=0.015)$, smoking as a rebellion form to parents $(\mathrm{P}=0: 03)$, smoking as a form of daily routine fracture $(\mathrm{P}=0.001)$ as well as smoking helps in socialization $(\mathrm{P}$ $=0.04$ ). About $89.1 \%$ of respondents have tried alcohol in their lifetime, and about $61.7 \%$ have drunk alcohol in the last month. It is men who consume more alcohol compared to women. Almost all young people have access to alcohol, as they can easily obtain it in bars, restaurants, events, or shops. Again, society is a very strong influencer in the use of alcoholic beverages $(\mathrm{P}<0.05)$. Only $0.6 \%$ of respondents have tried marijuana in their lifetime. The age when they first tried marijuana is 11-12 years old. Over the last 30 days, only $0.6 \%$ of students interviewed have used marijuana.

All mothers who are non-casual users of tobacco and alcoholic beverages are likely to become casual users of marijuana, so try it but not use it regularly.

\section{References}

1. Daniel Romer (2012). Adolescent Risk-Taking. Impulsivity and Brain development: Implications for prevention 53(3): 263-276.

\section{ISSN: 2574-1241}

DOI: 10.26717/BJSTR.2021.36.005885

Majlinda Zahaj. Biomed J Sci \& Tech Res

This work is licensed under Creative Commons Attribution 4.0 License

Submission Link: https://biomedres.us/submit-manuscript.php
2. Kipping RR, Campbell RM, MacArthur GJ, Gunnell DJ, Hickman M, et al. (2012) Multiple risk behavior in adolescence. J Public Health 2012, 34 (suppl_1): i1 - i2.

3. Dr. Vitori Hasani “Human sexuality ISBN 9789995691255 pp: 205

4. Kicaj E, Cercizaj R, Peto E, Coraj E (2015) Use of Alcohol among Young people: Evaluation of factors that Affecting its use. Journal of Education and Social Research, MCSER Publishing, May 2015; Rome Italy 5(2).

5. Dees WL, Hiney JK, Srivastava VK (2017) Alcohol and puberty. Alcohol Res. 38 (2): 277-282.

6. Jodi M Gilman, Sang Lee, John K Kuster, Myung Joo Lee Byoung Woo Kim, Andre van der Kouwe, et al. (2016) Variable activation in striatal subregions across components of a social influence task in young adult cannabis users 6(5): e00459.

7. Rowe CL, Liddle HA, Greenbaum PE, Henderson CE (2004) Impact of psychiatric comorbidity on treatment of adolescent drug abusers. J Subst Abuse Treat 2004 Mar 26 (2): 129-140.

8. Susan B Quello BA, BS Kathleen T Brady, Susan C Sonne (2005) Mood Disorders and Substance Use Disorder: A Complex Comorbidity Science and Practice perspectives 13-21.

9. Lipari RN, Ahrnsbrak RD, Pemberton MR, Porter JD (2012) Risk and Protective Factors and Estimates of Substance Use Initiation: Results from the 2016 National Survey on Drug Use and Health. 2017 Sep. In: CBHSQ Data Review. Rockville (MD): Substance Abuse and Mental Health. Services Administration (US); 2012. PMID: 29431965.

10. Mary-Anne Enoch (2012) The Influence of Gene - Environment Interactions on the Development of Alcoholism and Drug Dependence Curr Psychiatry Rep 14 (2): 150-158.

11. Michael J Mason, Jeremy Mennis (2012) An exploratory study of the effects of neighborhood characteristics on adolescent substance use. Addiction Research and Theory 18(1): 33-50.

12. Bruce Simons-Morton, Tilda Farhat (2010) Recent Findings on Peer Group Influences on Adolescent Substance Use. J Prim Prev 31 (4): 191208.

13. Tonmyr L, Thornton T, Draca J, Wekerle C (2010) A review of childhood maltreatment and adolescent substance use relationship. Current Psychiatry Reviews 6 (3): 223-234.

14. https://raisingchildren.net.au/teens/behaviour/behaviour-questionsissues/risky-behaviour

15.https://opa.hhs.gov/adolescent-health?adolescent-development/ substance-use/drugs/tabacco/ri sk-and-protective-factors/index. htms\#_ftn13

16. Ervin Toçi, Arjan Bregu, Dorina Toçi (2017) Trends of smoking prevalence among Albanian adolescents during 2011-2015: Results of ESPAD surveys. 1: 17-25.

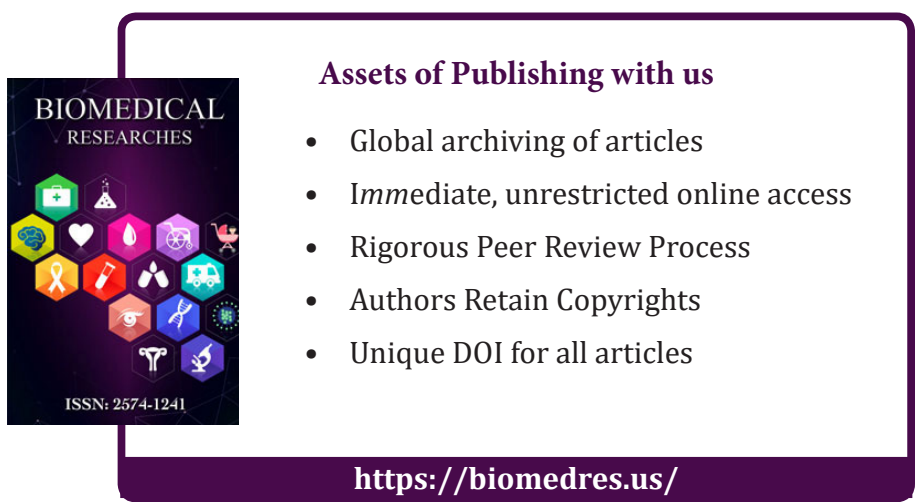

